$\infty$

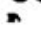

$\stackrel{\pi}{=}$

बํㅠㅁ
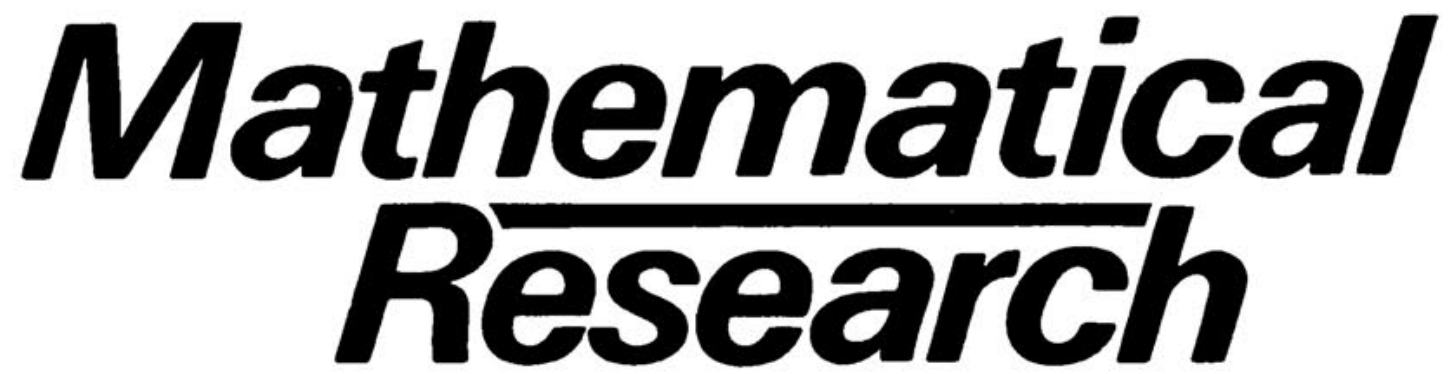

Parcella '88

edited by

G.Wolf $\cdot$ T.Legendi

U.Schendel

Band 48

48 AKADEMIE-VERLAG BERLIN 
In this series original contributions of mathematical research in all fields are contained, such as

- research monographs

- collections of papers to a single topic

- reports on congresses of exceptional interest for mathematical research.

This series is aimed at promoting quick information and communication between mathematicians of the various special branches.

Manuscripts

in English and German comprising at least 100 pages and not more than 500 pages can be admitted to this series. With respect to a quick publication the manuscripts are reproduced photomechanically. Authors who are interested in this series please turn directly to the 'Akademie-Verlag'. Here you will get more detailed information about the form of the manuscripts and the modalities of publication.
In diese Reihe werden Originalbeiträge zu allen Gebieten der mathematischen Forschung aufgenommen wie

- Forschungsmonographien

- Sammlungen von Arbeiten zu einem speziellen Thema

- Berichte von Tagungen, die für die mathematische Forschung besonders aktuell sind.

Die Reihe soll die schnelle Information und gute Kommunikation zwischen den Mathematikern der verschiedenen Fachgebiete fördern.

Manuskripte

in englischer und deutscher Sprache. die mindestens 100 Seiten und nicht mehr als 500 Seiten umfassen, können in diese Reihe aufgenommen werden. Im Interesse einer schnellen Publikation werden die Manuskripte auf fotomechanischem Weg reproduziert. Autoren, die an der Veröffentlichung entsprechender Arbeiten in dieser Reihe interessiert sind, wenden sich bitte direkt an den Akademie-Verlag. Sie erhalten dort genauere Informationen über die Gestaltung der Manuskripte und die Modalitäten der Veröffentlichung. 
Parcella ' 88 
Mathematical Research - Mathematische Forschung

Wissenschaftliche Beiträge

herausgegeben von der

Akademie der Wissenschaften der DDR

Karl-Weierstraß-Institut für Mathematik

\section{Band 48}

Parcella ' 88 


\section{Parcella '88}

Proceedings of the IV. International Workshop on Parallel Processing by Cellular Automata and Arrays

held in Berlin (GDR), October 17 - 21, 1988

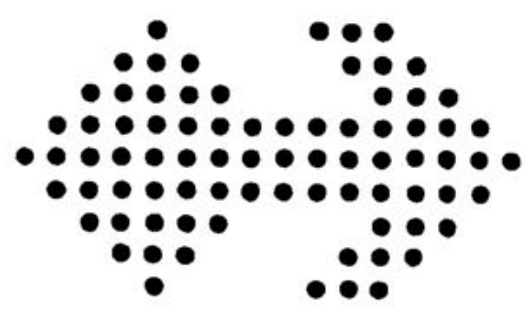

edited by

Gottfried Wolf

Tamás Legendi

Udo Schendel

Akademie-Verlag Berlin 1988 
Herausgeber:

Dr. Gottfried wolf

Akademie der Wissenschaften der DDR

Zentralinstitut für Kybernetik und Informationsprozesse, Berlin

Dr. Tamás Legendi

Hungarian Academy of Sciences

Research Group on Automata Theory, Szeged

Prot. Dr, Udo Schendel

Freie Universität Berlin

Institut für Mathematik lll, Berlin(West)

Die Titel dieser Schriftenreihe werden vom originalmanuskript der Autoren reproduziert.

ISBN 3-05-500656-9

ISSN $0138-3019$

Erschienen im Akademie-Verlag Berlin,DDR-1086 Berlin,Leipziger Str.3-4

(c) Akademie-Verlag Berlin 1988

Lizenznummer: 202.100/503/88

Printed in the German Democratic Republic

Gesamtherstellung: VEB Kongreß- und Werbedruck, 9273 Oberlungwitz

Lektor: Dr. Reinhard Höppner

LSV 1095

Bestellnummer: $763901 \circ(2182 / 48)$

05000 
This volume contains the selected papers for the Parcella 88 - The Fourth International Workshop "Parallel Processing by Cellular Automata and Arrays" was held in Berlin, October 17 - 21, 1988.

The profile of Parcella-workshop series is focused on problems of processing by regular structures, 1 . e. their "flexibilization" or adapting to "irregular" algorithms on the one hand and, closely related to this, on the "regularization" of algorithms for their embedding into regular structures. It seems that these problems will have an increasing priority within the list of central problems in parallelization and will determine the profile of Parcella for the next years.

This workshop - the first of this type in the socialist countries has gathered, as its predecessors, many scientists engaged and interested in this field. However, the organizers are of the opinion that some steps forward were taken as compared to the foregoing Parcella e.g. the size of the Parcella-community has increased, so that parallel sessions had to be held for the first time in our short Parcella-history, and the volume of the proceedings has increased, too. Nevertheless, the editors had to reject more than $50 \%$ of all papers submitted so that many of them, although of good quality, could be accepted for oral presentation only.

The organizers and promoters of the foregoing Parcella-events, T. Legend 1 and G. Wolf, has welcomed $U$. Schendel from Freie Universitaet (Berlin-West) as the third chairman at Parcella 88 . They 
are sure that this decision will support the future development immensely. They will make great efforts to provide a stimulating atmosphere and a fruitful exchange of ideas at this workshop and, by this, help to establish international cooperation in this highly dynamical field of research.

The work to be done by the Chairmen and Editorial Board with T. Legendl (Szeged), U. Schendel (Berlin-West) and G. Wolf (Berlin) was supported by the International Program Committee, consisting of V. Aladyev ( Tallinn), A. Albrecht (Berlin), W. Haendler (Erlangen), C. Jesshope (Southampton), A. Jugel (Dresden), N. Kasabov (Sof1a), E. Katona (Szeged), V. Kotov (Novosibirsk), S. Levialdi (Rome), I. Miklosko (Bratislava), D. Parkinson (London), A. Rosenfeld (P1ttsburgh), I. Toth (Szeged), J.-R. Sack (Ottawa), P. Spirakis (Patras), L. Uhr (Madison), R. Vollmar (Braunschweig), K. Voss (Jena): W. Wilhelmi (Berlin), G. Wunsch (Dresden) and C. K. Yap (New York). The chairmen would like to express their special thanks to Prof. Haendler and Prof. Vollmar for their kindness and help especially. They are very glad to welcome Prof. Haendler as honory lecturer.

The editors want to thank all contributors for their support to an interesting scientific program of high quality, and thank are also due to all authors who submitted papers for the proceedings even 1t they could not be accepted.

Finally, the editors are grateful to Prof. Dr. 8c. V. Kempe, Director of the supporting institute, the Central Institute for Cybernetics and Information Processes of the Academy of Sciences of the G.D.R., as the scientific adviser, and to Prof. Dr. sc. H. Fuchs, the Deputy Director of this institute, for their untiring efforts in helping to organize the workshop, as well as to Dr. Hoeppner and Ms. Dipl.-Math. Reiher from Akademie-Verlag and Dr. Woessner from Springer-Verlag as the publishing houses providing excellent conditions for the edition of this volume. 
The local chalrman wants to express his thanks to Dr. Creutzburg as the Head of the International Basic Laboratory "Image Processing and Computergraphics" for giving excellent conditions to prepare the workshop and to Prof. Wilhelmi for his help in preparing the scientific programme.

Furthermore, our thanks are due to Mrs. S. Boettcher, Mrs. I. Schubert and Mrs. M. Stabrey and the whole organizing staff, who did the main organizational work in the background.

Hoping to have provided the best conditions possible for Parcella 88 we look forward to a Parcella 90 , as the event to follow.

T. Legend1

U. Schendel

G. Wolf

(local chairman) 
